\title{
The effect of production system and management practices on the environmental impact, quality and safety of milk and dairy products
}

\author{
L.J. Erasmus ${ }^{\#}$ \& E.C. Webb
}

Department of Animal and Wildlife Sciences, University of Pretoria, Pretoria 0002, South Africa Associates of the Institute of Food Nutrition and Well-being, University of Pretoria, Pretoria 0002, South Africa

\footnotetext{
Copyright resides with the authors in terms of the Creative Commons Attribution 2.5 South African Licence.

See: http://creativecommons.org/licenses/by/2.5/za

Condition of use: The user may copy, distribute, transmit and adapt the work, but must recognize the authors and the South African Journal of Animal Science.
}

\begin{abstract}
There is an increasing trend to label milk and dairy products according to production system, absence of certain feed additives and non-use of specific technologies. These claims include the practice of organic farming, the absence of ionophore antibiotics and recombinant bovine somatotropin (r-bST) free milk. Absence-claim labels may imply to some consumers that certain milk is safer and more nutritious than other milk. Milk from r-bST supplemented cows is completely safe for human consumption, since bST is a protein, which is digested like other animal and plant proteins, it is species specific, and most bST in milk is denaturated by pasteurization. Fears of higher insulin growth factor 1 (IGF-1) levels in r-bST milk are unfounded, since these are insignificant compared with the daily secretion of IGF-1 in human saliva and gastro-intestinal secretions. r-bST does not affect milk composition. All milk (i.e. conventional, r-bST free and organic) is compositionally similar, and all milk is wholesome. Various studies have also confirmed that r-bST does not affect milk flavour or manufacturing characteristics that are important during the production of processed dairy foods such as cheese or yoghurt. There is no pathway for ionophore antibiotics from feed to milk and there is no scientific basis for concerns that these additives can give rise to transmissible resistance factors that may compromise the therapeutic use of antibiotics in humans. Organic farming is recognized as a possible way forward to improve sustainability in agriculture. However, it typically requires more resources and produces less food, which currently makes it less profitable and a questionable solution to meeting the world's growing food supply needs. Improving productive efficiency by using technologies is currently the most logical approach to mitigating the environmental impact of the dairy herd. The potential of r-bST and feed additives such as ionophore antibiotics to reduce greenhouse gas emissions should be recognized and implemented where applicable.
\end{abstract}

Keywords: Dairy production systems, r-bST, ionophores, organic milk

\#Corresponding author: lourens.erasmus@up.ac.za

\section{Introduction}

The value of dairy products in meeting the food security and nutritional needs of the global population is well recognized and included in dietary recommendations to promote health by governments and public health organizations around the world (Bauman \& Capper, 2011; Schönfeldt et al., 2013). Recent studies have revealed that high consumption of dairy products may help to reduce the risk of chronic diseases such as cardiovascular disease, diabetes, obesity, metabolic syndrome and many types of cancer (Elwood et al., 2008; Kliem \& Givens, 2012; Kratz et al., 2012). Overall, science demonstrates the importance of milk and dairy products in childhood development, health maintenance and the prevention of chronic diseases (Lock \& Bauman, 2011).

Recently certain milk processors and retailers began to make label claims describing specific production systems and management procedures on dairy farms, thereby confusing consumers by creating the impression that milk produced under specific conditions is healthier or safer than other milk. These 
claims include the practice of organic farming, the non-use of genetically modified organisms (GMOs), pesticides and ionophore antibiotics and the marketing of recombinant bovine somatotropin (r-bST) free milk. Absence-claim labels may imply that the labelled milk is safer or better than non-labelled milk because most consumers have little knowledge of on-farm feeding and management practices, milk processing and distribution to retail stores (Erasmus, 2007; Vicini et al., 2008).

The purpose of this paper is to clear misconceptions created by uninformed media, environmental activists and product labelling, and to provide readers with scientific facts regarding the effects of dairy production and management systems and technology on the safety and quality of milk and dairy products. The environmental impact of these practices is also discussed.

\section{Bovine Somatotropin (bST)}

Public perception of new technologies is an important component in the application of science, and this was especially true for bST as one of the first products of biotechnology. In the USA there were claims that the use of bST would cause cancer and an AIDS-like disease in humans; increase the amount of pus and antibiotics in milk; lower the quality and nutritional value; result in mad-cow disease and a catastrophic increase in mastitis; and cause hyper metabolic stress and burn-out in treated cows (Bauman, 1999). This was echoed in South Africa with media headlines such as "Crack for cows could be bad for you too" and "Cancer link to SA milk" (Erasmus, 2007). These perceptions have no substance. The scientific facts are discussed below.

\subsection{What is r-bST?}

Bovine somatotropin is a naturally occurring protein hormone produced by the anterior pituitary gland and is an important regulator of lactation in the cow. Circulating concentrations of bST are correlated positively with level of milk production (NRC, 2001). The US Food and Drug Administration (FDA) approved the commercial use of r-bST in 1993 for increasing milk production and efficiency based on scientific evidence collected to assess safety to consumers and cows (Juskevich \& Guyer, 1990; Bauman et al., 1994; Bauman, 1999).

Supplementation with r-bST involves biweekly subcutaneous injections in healthy cows from the ninth or tenth week of lactation, which is after cows have reached peak production, and milk production and circulating bST have declined (Vicini et al., 2008). The database on production responses is vast and shows that bST modifies the lactation curve by shifting to a higher level of milk production and improving persistency of lactation. On average, milk yield is increased by $10 \%-15 \%(4-6 \mathrm{~kg} / \mathrm{d})$ and is associated with a significant increase in feed efficiency of about 12\% (Bauman, 1992; Burton et al., 1994; NRC, 2001).

\subsection{Safety of milk from r-bST supplemented cows}

The safety for human consumption of milk from r-bST supplemented cows and the effect of r-bST on animal safety and health is still a concern for consumers. The FDA's conclusion that milk and meat from r-bST supplemented cows is safe was based on these scientifically established principles (Bauman, 1992; Vicini et al., 2008):

i) Bovine somatotropin is a protein and, like all other plant and animal proteins in the diet, is digested in the gastrointestinal (GI) tract to amino acids and peptides that do not have hormonal activity. This has been confirmed in studies with rats that were supplemented with up to 100 times the dose projected to be used commercially (on a $\mathrm{mg} / \mathrm{kg}$ body weight basis).

ii) Bovine somatotropin is species specific, and does not have biological effects in human beings, because the amino acid sequence of human somatotropin and bST differs by approximately 35\% (Juskevich \& Guyer, 1990). Owing to this difference, non-primate somatotropin, such as bST, does not bind to the human receptor, which is necessary for biological effects (Liu et al., 2001).

iii) Most bST in milk is denaturated by pasteurization and during processing for baby formula (Groenewegen et al., 1990).

The attention of activists has now turned to insulin-like growth factor-1 (IGF-1) since bST, whether natural or supplemented, increased milk production by promoting the production of the hormone IGF-1, and the IGF-1 is present in milk. Bovine and human IGF-1 are identical in structure. IGF-1 is a normal component in human gastro-intestinal (GI) secretions and plays a role in normal cell division. Concerns have 
been expressed that increased levels of IGF-1 in milk of r-bST supplemented cows might lead to increased cell division and growth of tumours in human beings. A consideration of the normal concentrations of IGF-1 in cow and human milk, as well as human body fluids, puts everything into perspective. A typical IGF-1 profile in cow's milk varies from $150 \mathrm{ng} / \mathrm{mL}$ after calving to $1.5 \mathrm{ng} / \mathrm{mL}$ at 200 days post partum. Some studies indicated no differences in IGF-1 between unsupplemented and r-bST supplemented cows, while others indicated a two- to fivefold increase after r-bST supplementation (1 - 9 vs. 1 - $13 \mathrm{ng} / \mathrm{mL})$. However, this is lower than the average for human milk $(5-10 \mathrm{ng} / \mathrm{mL})$, and minute compared with human plasma IGF-1 levels and daily IGF-1 GI secretions $\left(10^{7} \mathrm{ng} / \mathrm{mL}\right)$. If IGF-1 survived digestion and was absorbed intact, adults would need to consume 270 glasses of milk in a single day to equal the daily amount of IGF-1 produced in human saliva and other digestive secretions. It therefore poses no health risks (FAO/WHO, 1998).

\subsection{Effects of r-bST on milk composition, manufacturing properties of milk and dairy products}

The effect of r-bST on the gross composition of milk (fat, protein, lactose) has been examined in more than 200 trials (Bauman, 1992). During the first few weeks of lactation, there can be minor changes in the fat content of milk. However, these changes are temporary and insignificant compared with the variations that normally occur over a lactation period. The lactose content of milk is generally constant, but fat content and, to a lesser extent, content protein vary widely because of the influence of factors such as breed, genetics, age, stage of lactation, environment and season. These factors influence the gross composition of milk in an identical manner in r-bST supplemented and untreated cows (Peel \& Bauman, 1987; Barbano \& Lynch, 1989; Chalupa \& Galligan, 1989). Section 3.1 provides a detailed description of a large-scale study in which, in addition to milk components, milk quality and hormonal concentrations of milk between organic, conventional and r-bST free herds were compared.

Changes in milk composition can have a major impact on the manufacture of dairy products. Cheese yield for example can be affected by variations in the casein content of the milk, and by milk that is susceptible to oxidized and rancid milk flavours, and these effects will carry over into dairy products manufactured from that milk (Barbano \& Lynch, 1989). Results have been consistent that the dairy product manufacturing properties of milk from r-bST supplemented cows did not differ from those of unsupplemented cows (Barbano \& Lynch, 1989; Van den Berg, 1989). These evaluations included milk freezing point, $\mathrm{pH}$, alcohol stability, thermal properties, proteases, lipases, susceptibility to oxidation and sensory characteristics, including flavour of dairy products. In addition, no differences were found in cheesemaking properties or in the yield, composition or sensory properties of various cheeses (Bauman, 1992). In agreement, Laurent et al. (1992) reported no effect of r-bST on coagulation time, standard curd firmness, or soft or pressed cheese yields when compared with the milk from unsupplemented cows. Furthermore, milk and dairy products from cows supplemented with r-bST did not differ in concentration of vitamin A, thiamine, riboflavin, vitamin $B_{12}$, pantothenic acid or choline from milk of unsupplemented cows (Van den Berg, 1989).

\subsection{Effects of r-bST on animal health}

To verify that bST is safe for cows, the FDA required that safety margins should be established by treating cows with 60 times the commercial dose for two weeks and six times the commercial dose for two lactations. No effects were detected on animal health. Bauman (1992) also surveyed hundreds of r-bST studies and did not find any studies with increased incidence of ill health owing to r-bST supplementation.

There have also been claims that r-bST increases the incidence of clinical mastitis. The EU Committee on Veterinary Medical Products (CVMP) concluded that there was no evidence of an effect of r-bST supplementation on the incidence of mastitis. This is supported by many other studies (Bauman et al., 1999; Collier et al., 2001). The incidence of mastitis is linked to the level of milk production. In some studies r-bST supplemented cows have a higher incidence of mastitis and higher somatic cell count (SCC) in milk than lower-yielding controls, but these levels are comparable with untreated cows with a similar yield. A publication by the International Dairy Federation confirmed that r-BST supplementation has no effect on the incidence of mastitis (Bauman et al., 1994).

Discussions about potential increases in mastitis owing to r-bST supplementation have led to concern about greater use of antibiotics and their residues in milk. The FAO/WHO Expert Committee on Feed 
Additives concluded there is no higher risk and the potential for drug residues could be managed by practices currently in use by the dairy industry and by following label directions for antibiotic use (FAO/WHO, 1998).

\section{Ionophore Antibiotics}

Ionophore antibiotics are used extensively in many segments of the beef, poultry and dairy industries in many countries, including South Africa. In ruminants, ionophores inhibit gram-positive bacteria, which subsequently alter rumen fermentation patterns, resulting in increased amounts of energy and $\mathrm{N}$ from feeds in forms usable by the cow. Ionophores generally slightly decrease intake, but through ionophore-mediated alterations in rumen fermentation, they increase the supply of nutrients, especially propionate. This results in an increase in energy balance, which enhances milk production, efficiency of milk production and immune response (Ipharraguerre \& Clark, 2003). Owing to the increased energy status, cows in the transition period and early lactation in particular can benefit from ionophore supplementation. Ionophores contribute to lower mobilization of body reserves, as evidenced by lower blood non-esterified fatty acids and ketones, and increase in glucose. Animal manifestations include lower incidence of ketosis and displaced abomasum, lower loss of body condition, reduced incidence of acidosis and bloat, and increased milk production and efficiency (McGuffey et al., 2001). Comprehensive reviews on the mode of action of ionophores have been published (Bergen \& Bates, 1984; Russell \& Strobel, 1989; McGuffey, 1995).

\subsection{Effects on production}

Ipharraguerre \& Clark (2003) summarized results from 32 dairy cattle trials and found increased milk production after ionophore supplementation in 14 of the studies, ranging from $2.6 \%$ to $11.2 \%$ and averaging $7 \%(1.5 \mathrm{~kg} / \mathrm{d})$. Milk fat percentage is usually decreased by around 0.1 percentage unit and the response in milk protein is variable (Kennelly \& Lien, 1997). A meta-analysis on monensin supplementation involving 77 trials and nearly 10000 cows was published recently by Duffield et al. (2008). Supplemented cows increased milk production by $0.7 \mathrm{~kg} /$ day, decreased DMI by $0.3 \mathrm{~kg} /$ day and improved milk production efficiency by $2.5 \%$. Milk fat percentage was decreased $0.13 \%$ and milk protein percentage $0.03 \%$, but protein yield was increased and fat yield was not affected. Monensin was associated with a reduction in short chain fatty acids of $1 \%$ to $12 \%$, but conjugated linoleic acid was increased by $22 \%$. The data suggest that cows at greater risk of negative energy balance, such as early lactation and transition cows, as well as cows at greater risk of metabolic disorders (overconditioned cows) may benefit most from ionophores. Implementation strategies should target these cows in order to maximize economic returns (Ipharraguerre \& Clark, 2003).

\subsection{Public concern over the safety of ionophore antibiotic use}

Current livestock production systems face challenges and constraints, with the concept of "clean, green and ethical" animal production being promoted. "Clean" refers to the increased demand of consumers for safe high-quality and nutritious food that is manufactured with fewer synthetic inputs, in particular antibiotics. This led to the European Union banning the use of antibiotics (including ionophores) as animal growth promotants from January 2006 (EC, 2003). The scientific basis for these restrictions is associated with concern that the use of animal antibiotics in animal agriculture can give rise to transmissible resistance factors that may compromise the therapeutic use of antibiotics in human beings (Casewell et al., 2003). This scientific basis, however, is not well supported: i) ionophores have never been (nor are likely to be) used as an antimicrobial in human beings; ii) ionophores have a distinctly different mode of action from therapeutic antibiotics; and iii) ionophore resistance seems to be an adaptation rather than a mutation or acquisition of foreign genes.

Because Clostridium aminophilum $F$ could easily be adapted to ionophores, Houlihan \& Russell (2003) used this bacterium as model to determine whether ionophore resistance conferred increased resistance to other classes of antibiotics. Results showed that ionophore-resistant cultures of Clostridium aminophilum $F$ were as susceptible to other classes of antibiotics (penicillin, vancomycin, rifampin, polypeptides, tetracycline, erythromycin, chloramphenicol and norobiocin aminologlycocides) as ionophoresensitive ones. The only exception was bacitracin, an antibiotic used only in topical ointments, because it is too toxic for systemic use (Houlihan \& Russell, 2003). It was concluded that ionophores do not promote the development of antibiotic resistance because of their complex nature and high degree of specificity (Martinez \& Varga, 2007). 
Although ionophores such as monensin are not used in human medicine, people exposed to monensin during its manufacture had symptoms including headache, nose bleed, nausea and skin rash, and ranchers who fed monensin to cattle experienced headache and dizziness (Pressman, 1985). Although scientific data indicates that milk and meat from animals supplemented with ionophores are safe for human consumption (Donoho, 1984; Wilkinson et al., 1997), milk marketing campaigns still use the absence-claim on the label. One example is Sno-Fresh dairy in Washington, which sells milk with the label "Free of antibiotics, rumensin and r-bST". Wilkinson et al. (1997) reported that in eight studies in which monensin doses ranged from $278 \mathrm{mg} / \mathrm{d}$ to $1125 \mathrm{mg} / \mathrm{d}$ per cow, no residues of monensin were detected. The assays were highly sensitive, $0.005 \mu \mathrm{g} / \mathrm{mL}$ or $1 \mathrm{~g}$ monensin in $2000 \mathrm{~L}$ of milk. Furthermore, monensin is highly degradable in manure and soil and is not toxic to crop plants (Donoho, 1984). There is therefore no scientific basis for questioning the safety of milk for human consumption from cows supplemented with ionophores.

\section{Organic vs conventional production systems}

Organic farming is recognized as a possible way forward to improve sustainability in agriculture (Rigby \& Caceres, 2001). The main aim of organic farming is to create a sustainable agricultural production system, including economic, environmental and social sustainability. Organic farming is based on legislation, for example EU Council Regulation (EC) No 1804/1999 (European Council, 1991). Organic farming is thus defined and distinguished from conventional farming systems by a set of injunctions. Organic farming deals with grass and roughage production (no artificial fertilizers), grassland management (outdoor grazing prescribed), feeding (not more than $40 \%$ concentrates, no urea, purchased roughage organically produced, no GMOs) and animal healthcare (ban on preventative use of antibiotics and other regular medicine) (Berentson et al., 2012). Organic farming also claims to provide benefits in terms of environmental protection, conservation of non-renewable resources, improved food quality and reorientation of agriculture toward areas of market demand (Lumpkin, 1994).

\subsection{Is organic milk more wholesome than r-bST free or conventional milk?}

Although science does not support most claims suggesting improved health, nutrition and safety from organic food versus conventional foods, the "good food, bad food" debates continue (Simmons, 2013). In a recent study, the Centre for Health Policy of Stanford University evaluated 237 reports and found little significant difference in health benefits between organic and conventional foods (Smith-Spangler, 2012).

To confuse consumers further, milk retail labels such as r-bST free milk, organic milk and monensinfree milk refer to different production and management systems, and these labels are not predictive of milk composition or nutritional value (Vicini et al., 2008). Since there is surprisingly little data that compare measurements of quality, nutrient and hormonal composition of milk by three labels related to dairy farm management, a comparison survey study was conducted by Vicini et al. (2008). The survey included 334 retail milk samples from 48 states in the US that were categorized as conventional, r-bST free and organic milk labels. Milk samples were compared for nutritional value (fat, protein, solids non-fat) quality (antibiotics and bacterial count) and hormonal composition (somatotropin, IGF-1, oestradiol and progesterone). The results are shown in Table 1.

Results indicate few and minor differences in the composition of conventional, r-bST free or organic labelled milk and that all milk is wholesome. This is based on specific analyses that represented milk quality, and nutrients and hormones found in milk. The use of r-bST does not affect milk composition and milk from all three production systems (conventional, r-bST free, organic) is compositionally similar.

In another study, Mullen et al. (2012) compared milk from seven organically managed herds and seven conventionally managed herds in North Carolina. No difference was observed in SCC between organic and conventional dairies. The prevalence of several mastitis-causing bacteria, including Staphyllococcus aureus, Streptococcus spp. and Corynebacterium spp., did not differ. Despite differences in management, milk quality was remarkably similar between organic and conventional dairies. Hardeng \& Edge (2001) compared milk somatic cell count (SCC) between 31 organic and 93 conventional herds in Norway and found no marked difference between the two production systems.

There is a great deal of interest in the conjugated linoleic acid (CLA) content of milk owing to reported health benefits such as being anti-carcinogenic, anti-diabetic, anti-adipogenic and anti-atherogenic 
(Banni et al., 2003). It is well established that cows fed only pasture have higher milk CLA concentrations, specifically the cis 9 trans 11 isomer (Khanal et al., 2005). Compared with conventionally produced milk, organically produced milk has higher fat proportions of cis 9 trans 11 CLA and lower proportions of n-6 fatty acids (Collomb et al., 2008). However, conventional total mixed rations (TMR) based diets can yield high milk CLA levels by supplementing fish or sunflower oil, processing of oilseeds, or supplementing rumen protected CLA isomers (Khanal et al., 2007).

Table 1 Least square means for nutritional, quality and hormonal parameters in milk with labels related to three dairy farm production and management systems (Vicini et al., 2008)

\begin{tabular}{lcccc}
\hline \multirow{2}{*}{ Item } & \multicolumn{3}{c}{ Retail milk label } & \multirow{2}{*}{$\boldsymbol{P}$} \\
\cline { 2 - 4 } & Conventional & r-bST free & Organic & \\
\hline Bacterial count (1000 cfu/mL) & $11^{\mathrm{a}}$ & $26^{\mathrm{b}}$ & $22^{\mathrm{c}}$ & 0.0001 \\
Fat (\%) & 3.30 & 3.38 & 3.38 & 0.488 \\
Lactose (\%) & 4.71 & 4.70 & 4.67 & 0.155 \\
Protein (\%) & $3.14^{\mathrm{a}}$ & $3.15^{\mathrm{a}}$ & $3.22^{\mathrm{b}}$ & 0.001 \\
Total solids (\%) & 12.07 & 12.16 & 12.20 & 0.189 \\
Solids non-fat (\%) & 8.77 & 8.77 & 8.52 & 0.010 \\
Bovine somatotropin (ng/mL) & 0.005 & 0.0024 & 0.002 & 0.098 \\
Insulin-like growth factor 1 (ng/mL) & $3.12^{\mathrm{a}}$ & $3.04^{\mathrm{a}}$ & $2.73^{\mathrm{b}}$ & 0.001 \\
Progesterone (ng/mL) & $12.0^{\mathrm{a}}$ & $12.8^{\mathrm{a}}$ & $13.9^{\mathrm{b}}$ & 0.019 \\
Oestradiol (pg/mL) & $4.97^{\mathrm{a}}$ & $6.63^{\mathrm{b}}$ & $6.40^{\mathrm{b}}$ & 0.045 \\
& & & & \\
\hline
\end{tabular}

${ }^{\mathrm{ab}}$ Values within rows with different superscripts are different $(P<0.05)$.

From the scientific literature, it can be concluded that there are few and minor differences in the composition of conventional, r-bST free or organic labelled milk and all milk is wholesome. The important point is that consumers should be given a choice of milk from different production systems and not be confused by unsubstantiated "free from" labels that create the impression that some milk is of higher quality and more nutritious than others.

\section{Impact of new technology on the environment}

The UN projects that the world population will reach 9+ billion people by 2050, which would require a $100 \%$ increase in food production being produced on virtually the same land area as today. The FAO states that $70 \%$ of these additional food supplies must come from the use of efficiency-enhancing technologies (Simmons, 2009). Organic food production typically requires more feed resources and produces less food, which currently makes it a questionable solution to meeting the world's growing food supply. Productivity is significantly lower under organic management systems, with reductions in milk yield ranging from $15 \%$ to 27\% (USDA, 2007). When differences in productivity are accounted for, organic dairy production requires considerably more feed, land and water resources per unit of milk, and has a greater environmental impact (Capper et al., 2008; Capper, 2013).

Globally, animal agriculture is estimated to contribute approximately $18 \%$ of total greenhouse gas (GHG) emissions, and the dairy industry is often targeted as being particularly detrimental to the environment (Steinfield et al., 2006). Feed and milk production comprise about $80 \%$ of the total environmental impact of dairy foods in industrialized countries and even a greater percentage in developing world regions (UN/FAO, 2010).

More recent estimates are that animal agriculture contributes $14.5 \%$ of total GHG emissions and dairy milk production about $2.9 \%$ and $4 \%$, if meat from dairy herds is added (Gerber et al., 2013). In South Africa the figure for animal agriculture is about $5 \%-6 \%$, with milk production contributing about $10 \%$ of that (Meissner et al., 2013). 


\subsection{Impact of technology in the dairy industry}

Improving productive efficiency by using technologies is currently the most logical approach to mitigate the environmental impact of the dairy herd. The US dairy industry has made huge advances in efficiency over the past 60 years. In 1944, cow numbers peaked at 25.6 million, with total milk production of 53 billion kg; in 2007, 9.2 million animals produced 84 billion kg of milk, and production per cow increased fourfold. This improvement has been achieved through production and management practices that maximize potential yields, while emphasizing cow health and welfare (Capper et al., 2008). Furthermore, there has been a $63 \%$ reduction in the carbon footprint per $\mathrm{kg}$ of milk. The production system of the 1940s (low-yielding pasture-based cows, and no antibiotics, inorganic fertilizers, GMOs or chemical pesticides) is similar to today's organic production systems. Studies investigating the environmental impact of organic systems found increased usage of resources and carbon footprint per kg of milk, compared with conventional production (De Boer, 2003; Williams et al., 2006).

Consumers often have a negative image of technology in agriculture. They regard genetic modification, antibiotics and hormone use as threats to human and animal health, despite assurances from reputable health organizations and government agencies. Dairy producers are encouraged to use these technologies to adopt management practices that contribute to improved environmental stewardship and conservation, including actions to reduce GHG emissions through reducing methane production (Capper et al., 2008). In the following section, the impact on the environment of two technologies, r-bST and ionophores, is discussed briefly.

\subsection{Impact of r-bST on the environment}

Over the past three decades, r-bST has provided the greatest technological contribution to improving dairy productive efficiency and reducing the environmental impact of dairying (Bauman, 1992; EPA, 1999; Bosch et al., 2006). Capper et al. (2008) developed a stochastic model to predict the environmental impact when comparing a r-bST group of 1 million cows with an unsupplemented group and with a r-bST production response of $4.5 \mathrm{~kg} / \mathrm{d}$. The annual milk production of the supplemented group was $14.1 \mathrm{billion} \mathrm{kg}$. However, to produce the same amount of milk from the control group would require an extra 157000 lactating cows and 177000 associated dry cows and heifers. The r-bST supplemented population required 2.3 million metric tons less feed, 540000 fewer acres of land for crop production, and significant savings in fertilizers and pesticides. In addition, less methane and nitrous oxide would be released into the atmosphere. The improved production efficiency with r-bST of these million cows reduced animal fossil fuel and electricity use by 729 million MJ and 156 million kWh, equivalent to heating and powering 16000 homes (EIA, 2001). The reduced water use was sufficient for 10000 homes. The supplemented population reduced the carbon footprint by 1.9 billion $\mathrm{kg} /$ annum, equivalent to removing 400000 cars from the road or planting 300 million trees (Capper et al., 2008). In a South African perspective, if one third of the dairy cows are supplemented with r-BST, these values can be divided by three. The potential for widespread usage of r-BST to mitigate the environmental impact of dairy production is therefore substantial.

\subsection{Impact of ionophores on the environment}

Although ionophores are sometimes perceived as unnatural chemical feed antibiotics, monensin is a naturally occurring compound produced by the bacterium Streptomyces cinnamonensis. Monensin increases the efficiency of energy metabolism in the rumen. While the total VFA concentration in the rumen does not change, molar proportions of acetate and butyrate decrease, propionate increase and ruminal production of methane can be reduced by as much as 31\% (Stewart et al., 1987). Sauer et al. (1997) found that feeding 240 $\mathrm{mg} / \mathrm{d}$ of monensin in diets containing $65 \%$ forage and 35\% concentrate reduced methane output by $21 \%$. Similar results were obtained by Fellner et al. (1997), who added various ionophores to continuous ruminal fermenters at $2 \mu \mathrm{g} / \mathrm{mL}$ of culture. Van Vugt et al. (2005) fed cows on ryegrass-dominated pastures and measured a 9\% reduction in methane emissions (g/kg DMI), which persisted for more than two months after monensin controlled-release capsules were given. With TMRs, Odongo et al. (2007) reported a 3.6\% reduction (g/kg DMI) in methane for cows consuming a diet containing $24 \mathrm{mg}$ monensin/kg DM. Beachemin et al. (2008) provided evidence that the effect of monensin on CH4 emissions may be dose dependent; a dose of $<15 \mathrm{mg} / \mathrm{kg}$ DM did not reduce CH4 emissions, while a dose of $24-35 \mathrm{mg} / \mathrm{kg} \mathrm{DM}$ reduced CH4 emissions 
by $3 \%$ to $8 \%$ (g/kg DMI). Although results are variable, ionophores have great potential to reduce methane production in dairy cows.

\section{Conclusions}

Various health and governmental organizations have concluded that milk from r-bST cows is safe for human consumption, based on these scientifically established facts: i) bovine somatotropin is a protein hormone and, like all other animal and plant proteins, is digested in the gastrointestinal tract; ii) bovine somatotropin is species specific and does not have biological effects in humans, and iii) most bST in milk is denaturated by pasteurization. IGF-1 levels in cow's milk on average are higher than in human milk and are minute compared with daily IGF-1 secretion in human saliva and GI secretions and therefore pose no human health risks. There are few and minor differences in the composition of milk produced under different production systems (conventional, r-bST free, organic labelled milk), and all milk is wholesome. Various studies have also confirmed that r-bST has no effect on milk flavour or any of the manufacturing properties of milk that are important in the production of dairy products such as cheese and yoghurt. Public concern that the use of ionophore antibiotics in animal feed can give rise to transmissible resistance factors that may compromise the therapeutic use of antibiotics in humans is scientifically not well supported and there is no proven pathway of ionophores into milk. Organic food production systems typically require more resources, produce less food and have a higher carbon footprint/kg milk, which makes them a questionable solution to the world's growing food supply needs. Environmental impact, production system options and the use of technologies must be evaluated using whole system approaches based on productivity and efficiency rather than allowing ideological principles based on naïve or incomplete information or a lack of understanding future food production.

\section{References}

Banni, S., Heys, C.d.S. \& Wahle, K.W.J., 2003.Conjugated linoleic acid increases in milk when cows fed fish meal and extruded soybeans for an extended period of time. Livest. Sci. 114, 164-175.

Barbano, D.M. \& Lynch, J.M., 1989. Milk from bST treated cows: composition and manufacturing properties. In: Advanced Technologies Facing the Dairy Industry: bST. Mimeo Ser. No 133, Cornell Coop. Ext., Cornell Univ., Ithaca, NY. p. 9.

Bauman, D.E., 1992. Bovine somatotropin. Review of an emerging technology. J. Dairy Sci. 75, 3432-3451.

Bauman, D.E., 1999. Bovine somatotropin and lactation: From basic science to commercial application. Domest. Anim. Endocrinol, 17, 101-116.

Bauman, D.E. \& Capper, J.L., 2011. Sustainability and dairy production: challenges and opportunities. Proc. Cornell Nutr. Conf. Feed Manuf., Oct 18 - 30, Syracuse, NY. pp. 136-153.

Bauman, D.E., McBride, B.W. Burton, J.L. \& Sejrsen, K., 1994. Somatotropin (bST). International Dairy Federation, Bulletin 293, 2 - 7. IDF, Brussels, Belgium.

Bauman, D.E., Everett, R.W., Weiland, W.H. \& Collier, R.J., 1999. Production responses to bovine somatotropin in Northeast dairy herds. J. Dairy Sci. 82, 2564-2573.

Beachemin, K.A., Kreuzer, M., O’Mara, F. \& McAllistar, T.A., 2008. Nutritional management for enteric methane abatement: A review. Aust. J. Exp. Agric. 48, 21-27.

Berentson, P.B.M., Kovacs, K. \& Van Asseldonk, M.A.P.M., 2012. Comparing risk in conventional and organic dairy farming in the Netherlands: An empirical analyses. J. Dairy Sci. 95, 3803-3811.

Bergen, W.G. \& Bates, D.B., 1984. Ionophores: Their effect on production efficiency and mode of action. J. Anim. Sci. 58, 1465-1483.

Bosch, D.J., Wolfe, M.L. \& Knowlton, K.F., 2006. Reducing phosphorus runoff from dairy farms. J. Environ. Quality 35, 918-927.

Burton, J.L., McBride, B.W., Block, E., Glimm, D.R. \& Kennelly, J.J., 1994. A review of bovine growth hormone. Can. J. Anim. Sci.742, 167-201.

Capper, J.L., 2013. Should we reject animal source foods to save the planet? A review of the sustainability of global livestock production. S. Afr. J. Anim. Sci. 43, 233-246.

Capper, J.L., Cady, R.A. \& Bauman, D.E., 2008. Proc. Cornell Nutr. Conf. Feed Manuf. Oct 21 - 23, Syracuse, NY. pp. 55-64, 
Casewell, M., Friss, C., Granell, E.M., McMullin, P. \& Phillips, I., 2003. The European ban on the growth promoting antibiotics and its consequences for animal and human health. http://www.fedesa.be/news/news18-annex1.htm.

Chalupa, W. \& Galligan, D.T., 1989. Nutritional implications of somatotropin for lactating cows. J. Dairy Sci. 72, 2510-2524.

Collier, R.J., Byatt, J.C., Denham, S.C., Eppard, P.J., Fabellar, A.C., Hintz, R.L., McGrath, M.F., McLaughlin, C.L., Shearer, J.K., Veenhuïzen, J.J. \& Vicini, J.L., 2001. Effects of sustained release bovine somatotropin (sometribove) on animal health in commercial dairy herds. J. Dairy Sci. 84, 1098-1108.

Collomb, M., Bissig, W., Butikofer, U., Sieber, R., Bregg, M. \& Eher, L., 2008. Fatty acid composition of mountain milk from Switzerland: Comparison of organic and integrated farming systems. Int. Dairy J. 18, 976-982.

De Boer, I.J.M., 2003. Environmental impact assessment of conventional and organic milk production. Livest. Prod. Sci. 80, 69-77.

Donoho, A.L., 1984. Biochemical studies on the fate of monensin in animals and the environment. J. Anim. Sci. 58, 1528-1539.

Duffield, T.F., Rabiee, A.R. \& Lean, I.J., 2008. A meta-analysis of the impact of monensin in lactating dairy cattle. Part 2. Production effects. J. Dairy Sci. 91, 1347-1360.

EC, 2003. Regulation EC No 1831 / 2003 of the European Parliament and Council of 22 Sept 2003 on Additives for use in Animal Nutrition. J. Eur. Commun. L 268, 29-43.

EIA, 2001. Total energy consumption in US households by urban/rural location, 2001. Energy Information Administration, Washington, D.C., USA.

Elwood, P.C., Givens, D.I., Beswick, A.D., Fehili, A.M., Pickering, J.E. \& Gallacher, J., 2008. The survival advantage of milk and dairy consumption: an overview of evidence from cohort studies of vascular diseases, diabetes and cancer. J. Am. Coll. Nutr. 723S-734S.

Environmental Protection Agency (EPA), 1999. US methane emissions 1990-2020: Inventories, projections and opportunities for reductions. EPA, Washington, D.C., USA.

Erasmus, L.J., 2007. The truth on r-BST. Food Review 5, 16-18.

European Commission, 1999. Press release: Commission proposes ban on BST. IP/99/798, Brussels, Belgium, October 26, 1999.

European Council, 1991. Regulation EEC No 2092/1991. Regulation on organic production of agricultural products and indications referring thereto on agricultural products and foodstuffs. Off. J. Eur. Communities L198, 1-15.

FAO/WHO, 1998. Joint FAO/WHO Expert committee on food additives. Fifteenth meeting. Toxicological evaluation of certain veterinary drug residues in food, summary and conclusions. World Health Organisation, Geneva.

Fellner, V., Sauer, F.D. \& Kramer, J.K.G., 1997. Effect of nigericin, monensin and tetronasin on biohydrogenation in continuous flow - through ruminal fermenters. J. Dairy Sci. 80, 921-928.

Gerber, P.J., Steinfeld, H., Henderson, B., Mollet, A., Opio, C., Dijkman, J., Falcucci, A. \& Tempio, G., 2013. Tackling climate change through livestock - A clobal assessment of emissions and mitigation opportunities. Food and Agriculture Organization of the United Nations (FAO), Rome.

Groenewegen, P.P., McBride, B.W., Burten, J.H. \& Elasser, T.H., 1990. Bioactivity of milk from bSTtreated cows. J. Nutr. 120, 514-520.

Hardeng, F. \& Edge, V.L., 2001. Mastitis, ketosis and milk fever in 31 organic and 93 conventional Norwegian dairy herds. J. Dairy Sci. 84, 2673-2679.

Houlihan, A.J. \& Russel, J.B., 2003. The susceptibility of ionophore resistant Clostridium aminophilum F to other antibiotics. J. Antimicrob. Chemoth. 52, 623-628.

Ipharraguerre, I.R. \& Clark, J.H., 2003. Usefulness of ionophores for lactating dairy cows: a review. Anim. Feed Sci. Technol. 106, 39-57.

Juskevich, J.C. \& Guyer, C.G., 1990. Bovine growth hormone: Human food safety evaluation. Science 249, 875-884.

Kennelly, J.J. \& Lien, K.A., 1997. Effect of ionophore supplementation on milk components from lactating cows. Proc. Usefulness of Ionophores in Lactating Dairy Cattle. Ontario Vet. College, Ontario, Canada. pp. 40-49. 
Khanal, R.C., Dhiman, T.R., Ure, A.L., McMahon, D.J. \& Boman, R.L., 2005. Consumer acceptability of CLA-enridged milk and cheddar cheese from cows grazing on pasture. J. Dairy Sci. 88, 1837-1847.

Khanal, R.C., Dhiman, T.R. \& Boman, R.L., 2007. Changes in fatty acid composition of milk from lactating dairy cows during transition to and from pasture. Livest. Sci. 114, 164-175.

Khanal, R.C., Dhiman, T.O. \& Boman, R.L., 2008. Changes in fatty acid composition of milk from lactating cairy cows during transition to and from pasture. Livest. Sci. 114, 164-175.

Kliem, K.E. \& Givens, D.I., 2012. Dairy products in the food chain: their impact on health. Ann. Rev. Food Sci. 2, 21-36.

Korhonan, H.J., 2012. Production and properties of health promoting proteins and peptides from bovine colostrum and milk. Cell. Mol. Biol. 58, 26-38.

Kratz, M., Baars, T. \& Guyenet, S., 2012. The relationship between high fat dairy consumption and obesity, cardiovascular and metabolic disease. Eur. J. Nutr. DO7 10.1007/s 00394-012-0418-1.

Laurent, F., Vignon, B., Coomans, D., Wilkinson, J. \& Bonnell, A., 1992. Influence of bovine somatotropin on the composition and manufacturing properties of milk. J. Dairy Sci. 75, 2226-2234.

Liu, J.C., Makova, A.D., Adkins, R.M., Gibson, S. \& Li, W.H., 2001. Episodic evolution of growth hormones in primates and emergence of the species specificity of human GH receptor. Mol. Biol. Evol. 19, 945-953.

Lock, A.L. \& Bauman, D.E., 2011. Milk fat and human health - separating facts from fiction. Proc. Cornell Nutr. Conf. Oct 18 - 20, Syracuse, NY. pp. 126-135.

Lumpkin, N.H., 1994. Organic farming: Sustainable agriculture in practice. In: Economics of Organic Farming: An international perspective. Eds: Lumpkin, N.H. \& Padel, S., Centre for Agricultural Bioscience International (CABI), Wallingford, UK. pp. 3-9.

Martinez, M. \& Varga, G., 2007. Rumensin free milk - more smoke and mirrors. Internal publication. Dept Dairy and Animal Science, Penn State University, USA.

McGuffey, R.K., 1995. Potential for improving productive efficiency of lactating dairy cows through use of ionophores. Proc. Maryland Nutr. Conf. Feed Manuf. pp. 90-99.

McGuffey, R.K., Richardson, L.F. \& Wilkinson, J.Z.D., 2001. Ionophores for dairy cattle. Current status and future outlook. J. Dairy Sci. 84 (E Suppl.), E 194-E 203.

Meissner, H.H., Scholtz, M.M. \& Engelbrecht, F.A., 2013. Sustainability of the South African livestock sector towards 2050. Part 2: Challenges, changes and required implementations. S. Afr. J. Anim. Sci. 43, 298-319.

Mullen, K.A.E., Sparks, L.G., Lyman, R.L., Washburn, S.P. \& Anderson, K.L., 2012. Comparisons of milk quality on North Carolina organic and conventional dairies. J. Dairy Sci. 96, 6753-6762.

NRC, 2001. Nutrient requirements of dairy cattle. National Research Council, National Academy Press, Washington, D.C., USA.

Odongo, N.E., Bagg, R., Vessie, G., Dick, P., Or-Raschid, M.M., Hook, S.E., Gray, J.T., Kebrehab, E., France, J. \& McBride, B.W., 2007. Long-term effects of feeding monensin on methane production in lactating dairy cows. J. Dairy Sci. 90, 1781-1788.

Peel, C.J. \& Bauman, D.E., 1987. Somatotropin and lactation. J. Dairy Sci. 70, 474-486.

Pressman, B.C., 1985. The discovery of ionophores: An historical account. In: Antibiotics and their complexes. Ed: Sigel, H., Marcel Dekker Inc., NY. pp. 1-18.

Rigby, D. \& Caceres, C., 2001. Organic farming and the sustainability of agricultural systems. Agric. Syst. $68,21-40$.

Russell, J.B. \& Strobel, H.J., 1989. Effects of ionophores on ruminal fermentation. Appl. Environ. Microbiol. 55, 1-6.

Sauer, F.D., Fellner, V., Kinsman, R., Kramer, J.K.G., Jackson, H.A., Lee, A.J. \& Chen, S., 1997. Methane output and lactation response in Holstein cattle with monensin or unsaturated fat added to the diet. J. Anim. Sci. 76, 906-914.

Schönfeldt, H.C., Pretorius, B. \& Hall, N., 2013. The impact of animal source food products on human nutrition and health. S. Afr. J. Anim. Sci. 43, 394-412.

Simmons, J., 2009. Technology's role in the $21^{\text {st }}$ century. Food economics and consumer choice: Why agriculture needs technology to help meet a growing demand for safe nutritious and affordable food. Proc. Cornell Nutr. Conf. Feed Manuf., Syracuse, NY. pp. 171-185. 
Simmons, J., 2013. Enough - A manifesto. Elanco Animal Health 2500 Innovation Way, Greenfield, I.N., USA.

Smith-Spangler, 2012. Are organic foods safer or healthier than conventional alternatives? A systematic review. Ann. Int. Med. 157, 5-25.

Steinfeld, H.P., Gerber, P., Wassenaar, T., Castel, V., Rosales, M. \& de Haan, C., 2006. Livestock’s long shadow: Environmental issues and options. FAO, Rome. p. 390.

Stewart, C.S., Duncan, S.A. \& Joblin, K.N., 1987. Antibiotic manipulation of rumen microflora. In: Recent Advances in Anaerobic Microbiology. Eds: Barrielo, S.D. \& Hardie, J.M., Martinus Nijhoff, The Hague, Holland. pp. 108-109.

UN Food and Agricultural Organisation, 2010. Greenhouse gas emissions from the dairy sector. A life cycle assessment. Available at http://ww.fao.org/docrep/012/k7930e/k7930e00.pdf.

USDA, 2007. Dairy 2007, Part 1: Reference of dairy cattle health and management practices in the United States, 2007, USDA - APHIS-VS, Fort Collins, CO.

Van den Berg, G., 1989. Milk from bST treated cows: Its quality and suitability for processing. In: Use of somatotropin in livestock production. Eds: Sejrsen, K., Vestergaard, M. \& Neimann-Sorrenson, A., Elsevier Appl. Sci., New York. p. 178.

Van Vugt, S.J., Waghorn, G.C., Clark, D.A. \& Woodward, S.L., 2005. Impact of monensin on methane eructation and performance of cows fed forage diets. Proc. N. Z. Soc. Anim. Prod. 65, 362-366.

Vicini, J., Etherton, T., Kris-Etherton, P., Ballam, J., Denham, S., Staub, R., Goldstein, D., Cady, R., McGrath, M. \& Lucy, M., 2008. Survey of retail milk composition as affected by label claims regarding farm management. J. Am. Diet. Assoc. 108, 1198-1203.

Wilkinson, J.I.D., Kennington, A.S., Ehrenfried, K.M., Moran, J.W. \& Buck, J.M., 1997. Human food safety with the use of monensin in lactating cows. Proc. Usefulness of Ionophores in Lactating Dairy Cattle. Ontario Veterinary College, Ontario, Canada. pp. 86-93.

Williams, A.G., Audsley, E. \& Sandars, D.L., 2006. Determining the environmental burdens and resource use in production of agricultural and horticultural commodities. Main Report, Defra Research Project IS0205. Cranfield University and DEFRA, Bedford, UK. 